\title{
ALAT BUKTI KETERANGAN SAKSI DALAM PERKARA PIDANA SESUDAH PUTUSAN MAHKAMAH KONSTITUSI No. 65/PUU-VIII/2010 TANGGAL 2 AGUSTUS 2011
}

\author{
SUPRIYANTA, BAMBANG ALI KUSUMO \\ Universitas Slamet Riyadi \\ uperprian@gmail.com
}

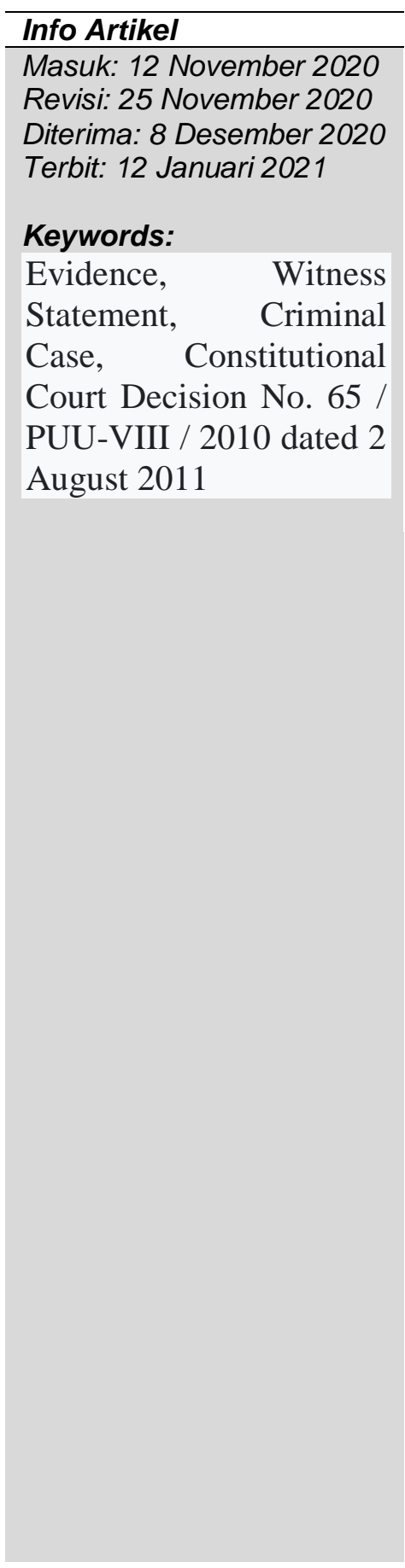

\begin{abstract}
This study is entitled evidence of witness testimony in criminal cases after the Constitutional Court decision No. 65 / PUU-VIII / 2010, dated August 2, 2011. The background of the problem is that juridically, theoretically, even practically, the evidence for witness testimony is what the witness heard himself, saw himself and experienced himself by mentioning the reasons for his knowledge. However, after the decision of the Constitutional Court No. 65 / PUU-VIII / 2010, there has been a fairly fundamental change because the interpretation of the Constitutional Court on witnesses and evidence of witness testimony includes people who can provide information in the context of investigation, prosecution and trial of a criminal act which he does not always hear himself, he saw for himself and he experienced it himself. The Constitutional Court's decision fundamentally changes the value of proof of witness testimony in criminal cases. The purpose of this research is to examine and describe the evidence of witness testimony in criminal cases and their juridical implications in criminal justice after the Constitutional Court decision No. 65 / PUUVIII / 2010, dated 2 August 2011.

Research method, this type of research is normative juridical research. The nature of the research is descriptive. The type of data used is secondary data. The data collection technique is done by using literature study. The data that has been collected are analyzed juridically qualitative.

The result of the research is that after the Constitutional Court decision no. 65 / PUU-VIII / 2010 dated August 2, 2011, there is an expansion of the concept of witness testimony which was originally "a person who can provide information in the context of investigation, prosecution and trial of a crime that he has heard himself, he has seen and experienced himself, which was later expanded to become "a person who can provide information in the context of investigating, prosecuting and judging a criminal act which he does not always hear himself, he sees and experiences himself.
\end{abstract}


Kata kunci:

Alat Bukti, Keterangan Saksi, Perkara Pidana, Putusan Mahkamah Konstitusi No. 65/PUU-VIII/2010 tanggal 2 Agustus 2011

P-ISSN: 2550-0171 E-ISSN: $2580-5819$ DOI : 103661

\section{PENDAHULUAN}

Dalam perkara pidana upaya mencari dan mendapatkan kebenaran materiil, dilakukan dengan pembuktian berdasarkan alat bukti yang sah menurut undang-undang. Alat

\begin{abstract}
Abstrak
Penelitian ini berjudul alat bukti keterangan saksi dalam perkara pidana sesudah putusan Mahkamah Konstitusi No. 65/PUU-VIII/2010, Tanggal 2 Agustus 2011. Latar belakang masalahnya adalah bahwa secara yuridis teoretis bahkan praktis alat bukti keterangan saksi adalah apa yang saksi dengar sendiri, ia lihat sendiri dan ia alami sendiri dengan menyebut alasan dari pengetahuannya itu. Namun sesudah putusan Mahkamah Konstitusi No. 65/PUUVIII/2010, telah terjadi perubahan yang cukup mendasar karena tafsir Mahkamah Konstitusi terhadap saksi dan alat bukti keterangan saksi termasuk juga orang yang dapat memberikan keterangan dalam rangka penyidikan, penuntutan, dan peradilan suatu tindak pidana yang tidak selalu ia dengar sendiri, ia lihat sendiri dan ia alami sendiri. Putusan MK tersebut merubah secara mendasar tentang nilai pembuktian keterangan saksi dalam perkara pidana.Tujuan penelitian ini adalah mengkaji dan mendeskripsikan alat bukti keterangan saksi dalam perkara pidana dan implikasi yuridisnya dalam peradilan pidana sesudah putusan Mahkamah Konstitusi No. 65/PUU-VIII/2010, tanggal 2 Agustus 2011.
\end{abstract}

Metode penelitian, Jenis penelitian ini adalah penelitian yuridis normatif. Sifat penelitian adalah deskriptif. Jenis data yang dipergunakan adalah data sekunder. Teknik pengumpulan data dilakukan dengan studi kepustakaan. Data yang sudah dikumpulkan dianalisis secara yuridis kualititatif.

Hasil penelitian bahwa sesudah putusan Mahkamah Konstitusi No. 65/PUU-VIII/2010 tanggal 2 Agustus 2011, ada perluasan konsep tentang keterangan saksi yang semula adalah "orang yang dapat memberikan keterangan dalam rangka penyidikan, penuntutan, dan peradilan suatu tindak pidana yang ia dengar sendiri, ia lihat sendiri dan ia alami sendiri, kemudian diperluas menjadi "orang yang dapat memberikan keterangan dalam rangka penyidikan, penuntutan, dan peradilan suatu tindak pidana yang tidak selalu ia dengar sendiri, ia lihat sendiri dan ia alami sendiri. 
bukti tersebut adalah sebagaimana tercantum dalam Pasal 184 Undang-undang No. 8 Tahun 1981 tentang Kitab Undang-Undang Hukum Acara Pidana ( selanjutnya KUHAP) yaitu keterangan saksi, keterangan ahli, surat, petunjuk dan keterangan terdakwa. Hal yang secara umum sudah diketahui tidak perlu dibuktikan.

Menurut Pasal 1 butir 26 KUHAP menyatakan : "Saksi adalah orang yang dapat memberikan keterangan guna kepentingan penyidikan, penuntutan dan peradilan tentang suatu perkara pidana yang ia dengar sendiri, ia lihat sendiri dan ia alami sendiri. Keterangan saksi adalah salah satu alat bukti dalam perkara pidana yang berupa keterangan dari saksi mengenai suatu peristiwa pidana yang ia dengar sendiri, ia lihat sendiri dan ia alami sendiri dengan menyebut alasan dari pengetahuannya itu. Pasal 65 KUHAP : "Tersangka atau terdakwa berhak untuk mengusahakan dan mengajukan saksi dan atau seseorang yang memiliki keahlian khusus guna memberikan keterangan yang menguntungkan bagi dirinya. Pasal 116 ayat 3 dan 4 KUHAP menyatakan : “(3) Dalam pemeriksaan tersangka ditanya apakah ia menghendaki didengarnya saksi yang dapat menguntungkan baginya dan bilamana ada maka hal itu dicatat dalam berita acara. (4) Dalam hal sebagaimana dimaksud dalam ayat (3) penyidik wajib memanggil dan memeriksa saksi tersebut".

Berdasarkan putusan Mahkamah Konstitusi No. 65/PUU-VIII/2010 tanggal 2 Agustus 2011, Pasal 1 angka 26 dan angka 27; Pasal 65; Pasal 116 ayat (3) dan ayat (4); serta Pasal 184 ayat (1) huruf a Undang-Undang Nomor 8 Tahun 1981 tentang Hukum Acara Pidana (Lembaran Negara Republik Indonesia Tahun 1981 Nomor 76 dan Tambahan Lembaran Negara Republik Indonesia Nomor 3209) tidak mempunyai kekuatan hukum mengikat sepanjang pengertian saksi dalam Pasal 1 angka 26 dan angka 27; Pasal 65; Pasal 116 ayat (3) dan ayat (4); Pasal 184 ayat (1) huruf a Undang-Undang Nomor 8 Tahun 1981 tentang Hukum Acara Pidana (Lembaran Negara Republik Indonesia Tahun 1981 Nomor 76 dan Tambahan Lembaran Negara Republik Indonesia Nomor 3209), tidak dimaknai termasuk pula "orang yang dapat memberikan keterangan dalam rangka penyidikan, penuntutan, dan peradilan suatu tindak pidana yang tidak selalu ia dengar sendiri, ia lihat sendiri dan ia alami sendiri'.Putusan MK yang bersifat final dan mengikat (binding) tersebut secara yuridis teoretis akan membawa implikasi yang serius dalam penilaian alat bukti keterangan saksi. Berdasarkan uraian di atas, maka permasalahan yang akan dikaji dalam penelitian ini adalah tentang konstruksi penilaian alat bukti keterangan saksi secara yuridis teoretis setelah adanya Putusan Mahkamah Konstitusi No.. 65/PUU-VIII/2010 tanggal 2 Agustus 2011

\section{METODE PENELITIAN}

Penelitian ini termasuk ke dalam jenis penelitian yuridis normatif. Penelitian ini bermaksud mendeskripsikan secara yuridis teoretis konstruksi penilaian alat bukti keterangan saksi dalam perkara pidana setelah Putusan Mahkamah Konstitusi No. No. 65/PUU- 
VIII/2010 tanggal 2 Agustus 2011. Penelitian ini bersifat deskriptif yang berusaha membuat deskripsi yuridis teoretis konstruksi penilaian alat bukti keterangan saksi dalam perkara pidana setelah Putusan Mahkamah Konstitusi No. No. 65/PUU-VIII/2010 tanggal 2 Agustus 2011. Bahan atau materi penelitian yang diperlukan meliputi : Bahan Hukum Primer yaitu : Undang-undang No.8 Tahun 1981 tentang Hukum Acara Pidana ( KUHAP); Putusan Mahkamah Konstitusi No. 65/PUU-VIII/2010 tanggal 2 Agustus 2011.Bahan Hukum Tersier seperti: Kamus Hukum Indonesia; Ensiklopedia Hukum Indonesia. Teknik pengumpulan data dalam penelitian ini dilakukan dengan cara mempelajari dan mengkaji perundang-undangan yang terkait dengan hukum acara pidana dan menelaah berbagai teori hukum, doktrin hukum, serta asas hukum yang relevan dengan pokok masalahnya. Metode analisis data yang dipergunakan adalah analisis secara kualitatif.

\section{HASIL PENELITIAN DAN PEMBAHASAN}

\section{A. Konstruksi Penilaian Alat Bukti Keterangan Saksi Dalam perkara Pidana.}

Pembuktian adalah fase terpenting dalam praktek penyelesaian perkara hukum di pengadilan. Dalam perkara pidana, kegiatan pembuktian in sudah dimulai sejak tahap penyidikan. Penentuan mengenai apa saja yang menjadi alat bukti suatu kasus pidana sudah diawali pada tahap penyidikan ini. Karena itu pada tahap ini penyidik harus sudah bisa menentukan mana saja yang merupakan alat bukti yang sah menurut hukum. Mengenai alat bukti yang sah ini ketentuan umum hukum acara pidana sebagaimana diatur dalam Undangundang No. 8 Tahun 1981 tentang Hukum Acara Pidana menyebutkan dengan jelas dalam Pasal 184 undang-undang dimaksud yaitu : Keterangan saksi; Keterangan ahli;Surat;Petunjuk, dan Keterangan terdakwa.

Khususnya mengenai alat bukti keterangan saksi, dalam KUHAP diatur hal-hal sebagai berikut :

"Pasal 185 KUHAP :

(1) Keterangan saksi sebagai alat bukti ialah apa yang saksi nyatakan di sidang pengadilan.

(2) Keterangan seorang saksi saja tidak cukup untuk membuktikan bahwa terdakwa bersalah terhadap perbuatan yang didakwakan kepadanya.

(3) Ketentuan sebagaimana dimaksud dalam ayat (2) tidak berlaku apabila disertai dengan suatu alat bukti yang sah lainnya.

(4) Keterangan beberapa saksi yang berdiri sendiri-sendiri tentang suatu kejadian atau keadaan dapat digunakan sebagai suatu alat bukti yang sah apabila keterangan saksi itu ada hubungannya satu dengan yang lain sedemikian rupa, sehingga dapat membenarkan adanya suatu kejadian atau keadaan tertentu.

(6) Dalam menilai kebenaran keterangan seorang saksi, hakim harus dengan sungguhsungguh memperhatikan persesuaian antara keterangan saksi satu dengan yang lain; persesuaian antara keterangan saksi dengan alat bukti lain; 
alasan yang mungkin dipergunakan oleh saksi untuk memberi keterangan yang tertentu; cara hidup dan kesusilaan saksi serta segala sesuatu yang pada umumnya dapat mempengaruhi dapat tidaknya keterangan itu dipercaya;

(7) Keterangan dari saksi yang tidak disumpah meskipun sesuai satu dengan yang lain, tidak merupakan alat bukti, namun apabila keterangan itu sesuai dengan keterangan dari saksi yang disumpah dapat dipergunakan sebagai tambahan alat bukti sah yang lain”.

Penjelasan Pasal 185 KUHAP : Ayat (1) Dalam keterangan saksi tidak termasuk keterangan yang diperoleh dari orang lain atau testimonium de auditu.

Ayat (6) Yang dimaksud dengan ayat ini ialah untuk mengingatkan hakim agar memperhatikan keterangan saksi harus benarbenar diberikan secara bebas, jujur dan obyektif.

Berdasarkan ketentuan di atas, dapat ditarik beberapa hal terkait dengan alat bukti keterangan saksi dalam perkara pidana :

Keterangan saksi yang sah dalam perkara pidana menurut hukum adalah keterangan saksi yang diberikan di depan sidang pengadilan. Ini artinya bahwa keterangan saksi yang dituangkan dalam berita acara pemeriksaan sebelum sidang pengadilan masih harus dikonfirmasi di depan sidang pengadilan.

Keterangan dari satu orang saksi tidak bisa untuk membuktikan kesalahan terdakwa. Ini yang disebut sebagai prinsip unus testis nullus testis 'satu saksi bukan saksi'. Keterangan satu saksi ini hanya bernilai sebagai alat bukti jika bersesuaian dengan alat bukti lain yang sah.

Jika keterangan beberapa saksi berdiri sendiri-sendiri berkenaan dengan kejadian atau keadaan, maka keterangan saksi tersebut hanya bernilai jika keterangan dari saksi-saksi tersebut ada hubungannya satu dengan yang lain yang membenarkan adanya suatu kejadian atau keadaan tertentu. Jadi keterangan saksi yang satu dengan yang lain itu bisa berssesuaian satu dengan yang lain, bisa juga bersifat ada hubungan satu dengan yang lain.

Penilaian terhadap kebenaran alat bukti keterangan saksi dalam perkara pidana ditentukan oleh persesuaian antara keterangan saksi satu dengan yang lain; persesuaian antara keterangan saksi dengan alat bukti lain; alasan yang mungkin dipergunakan oleh saksi untuk memberi keterangan yang tertentu; cara hidup dan kesusilaan saksi serta segala sesuatu yang pada umumnya dapat mempengaruhi dapat tidaknya keterangan itu dipercaya;

\section{B. Putusan Mahkamah Konstitusi}

Putusan MK No. 65/PUU-VIII/2010 yang diputuskan pada tanggal 2 Agustus 2011 telah memperluas pengertian keterangan saksi dalam Pasal 1 angka 26 dan angka 27; Pasal 65; Pasal 116 ayat (3) dan ayat (4); Pasal 184 ayat (1) huruf a KUHAP bertentangan dengan UUD 1945 sepanjang pengertian saksi dalam Pasal 1 angka 26 dan angka 27; Pasal 65; Pasal 116 ayat (3) dan ayat (4); Pasal 184 ayat (1) huruf a KUHAP. Intinya adalah memperluas pengertian keterangan saksi menjadi tidak hanya "orang yang dapat memberikan keterangan 
dalam rangka penyidikan, penuntutan, dan peradilan suatu tindak pidana yang ia dengar sendiri, ia lihat sendiri dan ia alami sendiri". Namun diperluas menjadi "orang yang dapat memberikan keterangan dalam rangka penyidikan, penuntutan, dan peradilan suatu tindak pidana yang tidak selalu ia dengar sendiri, ia lihat sendiri dan ia alami sendiri”. Mahkamah Konstitusi berpendapat dalam putusannya :

"bahwa pengaturan atau pengertian saksi dalam KUHAP, sebagaimana diatur dalam pasalpasal yang dimohonkan pengujian menimbulkan pengertian yang multitafsir dan melanggar asas lex certa serta asas lex stricta sebagai asas umum dalam pembentukan perundangundangan pidana. Ketentuan yang multitafsir dalam hukum acara pidana dapat mengakibatkan ketidakpastian hukum bagi warga negara, karena dalam hukum acara pidana berhadapan antara penyidik, penuntut umum, dan hakim yang memiliki kewenangan untuk memeriksa dengan tersangka atau terdakwa yang berhak untuk mendapatkan perlindungan hukum”.

Jadi menurut pendapat Mahkamah Konstitusi perumusan pengertian saksi dalam pasal-pasal yang dimintakan uji materi yaitu diPasal 1 angka 26 dan angka 27; Pasal 65; Pasal 116 ayat (3) dan ayat (4); Pasal 184 ayat (1) huruf a KUHAP bertentangan dengan UUD 1945 sepanjang pengertian saksi dalam Pasal 1 angka 26 dan angka 27; Pasal 65; Pasal 116 ayat (3) dan ayat (4); Pasal 184 ayat (1) huruf a KUHAP dianggap bertentangan dengan asas lex certa serta asas lex stricta. Asas lex certa artinya harus jelas apa maksud dan ruang lingkupnya sedangkan asas lex stricta artinya harus tertulis dan jelas batas-batasnya sehingga dengan kedua asas tersebut mencegah terjadinya multi tafsir dalam pengaturan pengertian tentang alat bukti keterangan saksi dalam perkara pidana.

\section{Implikasi Putusan Mahkamah Konstitusi Terhadap Alat Bukti Keterangan Saksi Dalam Perkara Pidana.}

Putusan Mahkamah Konstitusi tersebut secara konseptual telah merubah pemahaman secara mendasar terhadap pengertian saksi dalam perkara pidana. Dalam konsep lama sebelum adanya putusan Mahkamah Konstitusi tersebut, saksi adalah orang yang dapat memberikan keterangan guna kepentingan penyidikan, penuntutan dan peradilan tentang suatu perkara pidana yang ia dengar sendiri, ia lihat sendiri dan ia alami sendiri. Namun karena diperluas menjadi tidak harus yang selalu ia engar sendiri, ia lihat sendiri dan ia alami sendiri maka ada beberapa implikasi terkait dengan penilaian terhadap keterangan saksi sebagai alat bukti dalam perkara pidana. Implikasi tersebut menurut penulis adalah sebagai berikut :

Dalam hukum acara pidana dikenal saksi de auditu, yaitu saksi yang hanya mendengar dari orang lain. Dalam hukum saksi demikian tidak memiliki nilai pembuktian. Sejak adanya putusan Mahkamah Konstitusi tersebut maka dimungkinkan saksi de auditu tersebut bisa dipercaya bernilai sebagai keterangan saksi. 
Dalam hukum pidana yang dicari adalah kebenaran materiil, malalui alat-alat bukti yang sah menurut hukum. Keterangan saksi adalah salah satu alat bukti yang sah menurut hukum. Dalam hukum pidana ada asas bahwa unus testis nullus testis 'satu saksi bukan saksi'. Maknanya adalah jika tidak ada alat bukti apapun minimal harus ada 2 (dua) orang saksi. Jika dalam suatu kasus pidana ternyata hanya ada 2 (dua) orang saksi, maka jika mendasarkan pada Putusan Mahkamah Konstitusi tersebut dimungkinkan juga keterangan saksi yang tidak didengar, dilihat dan dialami sendiri menjadi dasar dalam penjatuhan putusan pidana, jika hakim yakin dengan keterangan saksi yang demikian itu.

\section{KESIMPULAN}

Kesimpulan dari uraian di atas adalah sebagai berikut :

Konstruksi Penilaian Alat Bukti Keterangan Saksi Dalam perkara Pidana telah mengalami perluasan yang semula saksi adalah "orang yang dapat memberikan keterangan dalam rangka penyidikan, penuntutan, dan peradilan suatu tindak pidana yang ia dengar sendiri, ia lihat sendiri dan ia alami sendiri, kemudian diperluas menjadi “orang yang dapat memberikan keterangan dalam rangka penyidikan, penuntutan, dan peradilan suatu tindak pidana yang tidak selalu ia dengar sendiri, ia lihat sendiri dan ia alami sendiri.

Implikasi teoretis dan praktis dari perluasan penafsiran keterangan saksi dalam perkara pidana oleh Mahkamah Konstitusi tersebut adalah dimungkinkannya saksi de auditu dapat diterima sebagai alat bukti dan dalam kasus pidana yang nyata jika hanya terdapat 2 (dua) orang saksi yang dimungkinkan juga keterangan 2 (dua) orang saksi de auditu tersebut menjadi dasar dalam penjatuhan pidana, jika hakim merasa yakin dengan adanya (2) saksi yang demikian itu.

\section{SARAN-SARAN}

Perubahan konsep keterangan saksi sesudah putusan Mahkamah Konstitusi No. 65/PUU-VIII/2010 tanggal 2 Agustus 2011 sebaiknya dipahami dalam konteks prinsip mencari kebenaran materiil berdasarkan keyakinan Hakim.

Jika dalam suatu kasus hanya ada 2 (dua) orang saksi yang keterangannya bersifat de auditu, maka sejak sebelum sidang pengadilan, koodinasi antara penyidik dan penuntut umum berkenaan dengan alat bukti tersebut harus dilakukan secara seksama. 


\section{A. DAFTAR PUSTAKA}

Andi Hamzah dan Irdan Dahlan. 1984. Perbandingan KUHAP, HIR dan Komentar. Jakarta : Ghalia Indonesia.

Abdulkadir Muhammad. 2004. Hukum dan Penelitian Hukum. Bandung : PT Citra Aditya Bakti : Bandung.

Lilik Mulyadi. 1996. Hukum Acara Pidana, PT. Citra Aditya Bakti, Bandung

M Yahya Harahap. 2001. Pembahasan Permasalahan dan Penerapan KUHAP. Jakarta : Pustaka Sinar Kartini.

M. Yahya Harahap. 2006. Pembahasan Permasalahan Dan Penerapan KUHAP Penyidikan Dan Penuntutan. Jakarta : Sinar Grafika.

Ronny Hanitijo Soemitro. 1990. Metodologi Penelitian Hukum dan Jurimetri. Jakarta : Ghalia Indonesia.

Soerjono Soekanto. 1986, Pengantar Penelitian Hukum, UI Press: Jakarta

Soerjono Soekanto, dan Sri Mamudji, 2006, Penelitian Hukum Normatif, Suatu Tinjauan Singkat, Jakarta : Rajagrafindo Persada.

Wirjono Prodjodikoro.1980. Tindak-Tindak Pidana Tertentu Di Indonesia. Jakarta, PT Eresco Jakarta-Bandung.

PERUNDANG-UNDANGAN DAN PUTUSAN HAKIM

Undang-Undang No. 8 Tahun 1981 Tentang Hukum Acara Pidana.

Putusan Mahkamah Konstitusi No. 65/PUU-VIII/2010, Tanggal 2 Agustus 2011 